\title{
Protein synthesis by bovine chorion and uterine endometrium during the period of implantation
}

\author{
D. Claire Wathes*
}

Department of Physiology and Environmental Studies, University of Nottingham School of Agriculture, Sutton Bonington, Loughborough, Leics, LE12 5RD, and A.R.C. Institute of Animal Physiology, Babraham, Cambridge CB2 4AT, U.K.

\begin{abstract}
Summary. A grid method for culturing bovine endometrial and chorion tissue is described. A peak of mol. wt 85000 was obtained only from chorion which had been cultured with intercotyledonary tissue but the co-culture of cotyledon, intercotyledon, kidney or liver with chorion obtained from cows 24-29 days pregnant did not significantly alter the overall level of protein synthesis. The addition of progesterone or oestradiol- $17 \beta$ to the culture medium $\left(10^{-4} \mathrm{~mol} / \mathrm{l}\right)$ significantly depressed protein synthesis by both chorion and uterine endometrium.
\end{abstract}

\section{Introduction}

The requirement of the blastocyst of the cow for the correct uterine environment has been demonstrated by embryo transfer experiments which show that an asynchrony of only plus or minus 1 day will lead to a significant reduction in successful pregnancies (Newcomb \& Rowson, 1975; Sreenan \& McDonagh, 1979). Pregnancy-specific proteins were found in bovine uterine flushings by Roberts \& Parker (1974) between Days 7 and 35 and by Laster (1977) from Day 15 of pregnancy onwards. However, these studies did not demonstrate conclusively whether the proteins were produced by the trophoblast or uterus. In rabbits and pigs there is a marked increase in the secretion of specific proteins (uteroglobin and uteroferrin respectively) from the endometrium into the uterine lumen at about the time of attachment (Beier, 1976; Schlosnagle, Bazer, Tsibris \& Roberts, 1974) and in both the secretion is progesterone-dependent.

The preimplantation bovine blastocyst is capable of synthesizing progesterone (Shemesh, Milaguir, Ayalon \& Hansel, 1979) and it has been shown to contain placental lactogen (Flint, Henville \& Christie, 1979). Furthermore, Eley, Thatcher \& Bazer (1979) have demonstrated the presence of oestrone sulphate of presumed fetal origin in the maternal plasma from Day 27 of gestation. The influence of these hormones on the mother during early pregnancy is unknown. The aim of this study was to examine the inter-relationship between the uterine endometrium and the chorion during the period of implantation in the cow, which occurs during the 4th week of gestation (Leiser, 1975).

\section{Materials and Methods}

The methodology is based on that reported by Wyatt (1976) and Rice (1978) for the pig.

* Present address: Department of Anatomy, The Medical School, Bristol BS8 1TD, U.K. 


\section{Culture medium}

Powdered Medium 199 (M199) containing Earle's salts and L-glutamine from Flow Laboratories was used. The $\mathrm{pH}$ was adjusted to 7.2 and 100 i.u. penicillin $/ \mathrm{ml}$ (Crystapen: Glaxo Laboratories Ltd), insulin ( $5 \mu \mathrm{g} / \mathrm{ml}$; BDH Biochemicals Ltd) and $10 \%$ fetal calf serum (Gibco-Biocult) were added. Radioactive leucine (L-[U- $\left.{ }^{14} \mathrm{C}\right]$ leucine, sp. act. $12 \mathrm{GBq} / \mathrm{mmol}$, or L-[4,5- ${ }^{3} \mathrm{H}$ [leucine, sp.act. $1.9 \mathrm{TBq} / \mathrm{mmol}$ : Radiochemical Centre, Amersham) was added initially at a concentration of $3.7 \times 10^{4} \mathrm{~Bq}$ per $3 \mathrm{ml}$ (i.e. per culture dish). This was increased later to $1.85 \times 10^{5} \mathrm{~Bq}$ per dish for $\left[{ }^{3} \mathrm{H}\right]$ leucine and $7.4 \times 10^{4} \mathrm{~Bq}$ per dish for $\left[{ }^{14} \mathrm{C}\right]$ leucine. In the first series of experiments concentrated solutions of oestradiol-17 $\beta$ and progesterone in alcohol were evaporated to dryness before adding culture medium to provide a final concentration of $0.3 \mu \mathrm{mol}$ steroid per culture dish (approximately $10^{-4} \mathrm{~mol} / \mathrm{l}$ ). All media were sterilized by passage through 0.45 or $0.22 \mu \mathrm{m}$ millipore filters. Media used during tissue dissection did not contain fetal calf serum or labelled leucine.

\section{Collection of tissue}

Friesian cows of known stages of pregnancy, 24-44 days after insemination, were killed by captive bolt pistol and exsanguinated. The reproductive tract was removed, wrapped in a sterile towel and transported to the laboratory in an insulated flask. The pregnant horn was opened in a laminar flow cabinet within $30 \mathrm{~min}$ of death and the fetus and membranes were removed and placed in Medium 199. Pieces of cotyledon and intercotyledonary tissue (approximately $5 \times 10$ $\mathrm{mm}$ ) were cut from the uterine wall and placed in medium. All tissues were dissected further before placing in culture dishes; the chorion and allantois were cut into lengths of about $5 \mathrm{~mm}$ and the endometrial tissue into pieces of about $2 \mathrm{~mm}^{3}$.

\section{Culture equipment}

The method used was similar to that described by Koren \& Behrman (1968) except that the cover slip was omitted. Tissue explants were cultured on a piece of lens tissue $(25 \times 20 \mathrm{~mm}$ Greens, C 105, Baird and Tatlock, Romford) prepared as described by Chen (1954). This was placed on a stainless-steel metal grid $(4 \times 25 \times 20 \mathrm{~mm})$, in a sterilized plastic Petri dish $(10 \times 30$ mm: Falcon Plastics) to which $3 \mathrm{ml}$ culture medium had been added. The meniscus of the medium was level with the top of the grid. Three small culture dishes were placed in a larger sterilized Petri dish $(10 \times 90 \mathrm{~mm}$ : Falcon Plastics $)$ lined with filter paper and moistened with 4 $\mathrm{ml}$ sterile water. These were incubated at $37^{\circ} \mathrm{C}$ in an atmosphere of $7 \% \mathrm{CO}_{2}$ in air for $48 \mathrm{~h}$.

\section{Experiments}

The effect of steroid treatment. Cows at 25, 34, 36 and 44 days of pregnancy were used. Pieces of chorion ( 1 or 2 pieces per dish) and cotyledon ( 3 pieces per dish) were placed with either ${ }^{14} \mathrm{C}$-labelled control medium or ${ }^{3} \mathrm{H}$-labelled medium containing oestradiol- $17 \beta(0.3 \mu \mathrm{mol} / 3$ $\mathrm{ml})$, progesterone $(0.3 \mu \mathrm{mol} / 3 \mathrm{ml})$ or both $(0.15 \mu \mathrm{mol}$ of each $/ 3 \mathrm{ml})$. There were 3 culture dishes per cow for each treatment.

Co-culture experiment. Cows at 24, 25, 26, 28 and 29 days of pregnancy were used. Pieces of chorion $(2 /$ dish $)$, cotyledon $\left(3 /\right.$ dish) or intercotyledon $\left(3 /\right.$ dish) were cultured with ${ }^{14} \mathrm{C}$-labelled medium as controls. Co-cultures were set up in which chorion (1 piece/dish) was placed on the same grid but not touching cotyledonary, intercotyledonary, liver or kidney tissue (2 pieces/dish) with ${ }^{3} \mathrm{H}$-labelled medium. Pieces of allantois (2/dish) were cultured alone in ${ }^{3} \mathbf{H}$-labelled medium. There were usually $\mathbf{5}$ dishes per cow for each treatment. at 04/26/2023 07:08:46AM 


\section{Analytical procedures}

Protein precipitation. Tissues and culture medium were analysed for the concentration of labelled proteins. Explants were homogenized in 1 or $2 \mathrm{ml} 1 \%$ sodium dodecyl sulphate. To 0.2 $\mathrm{ml}$ tissue homogenate or $0.3 \mathrm{ml}$ medium was added $0.3 \mathrm{ml} 10 \mathrm{~mm}$-sodium phosphate buffer, $\mathrm{pH}$ 7.2 , containing $0.15 \mathrm{M}-\mathrm{NaCl}, 0.08 \mathrm{M}-\mathrm{L}-\mathrm{leucine}$ and $2 \%(\mathrm{w} / \mathrm{v})$ bovine serum albumin. Proteins were precipitated by adding $1 \mathrm{ml} 10 \%$ trichloracetic acid (TCA) at $4{ }^{\circ} \mathrm{C}$. After centrifugation at $600 \mathrm{~g}$ for $3 \mathrm{~min}$ the supernatant was removed and the precipitate washed in a similar manner with $1 \mathrm{ml} 5 \%$ TCA. This step was repeated twice more. The final precipitate was dissolved overnight at $37^{\circ} \mathrm{C}$ in $750 \mu \mathrm{l}$ Soluene-350 (Packard Instruments Ltd, Caversham). ToluenePPO scintillant $(5 \mathrm{ml})$ was added and radioactivity was determined and corrected for quenching by using a channel's ratio method. The protein in each sample was measured as described by Lowry, Rosebrough, Farr \& Randall (1951) and the results were expressed in d.p.m. leucine incorporated per $\mathrm{mg}$ chorionic or endometrial protein.

Polyacrylamide gel electrophoresis. For sample preparation, replicate samples of medium or tissue homogenates were pooled and dialysed against $0.1 \%$ L-leucine in $5 \mathrm{~mm}$-Tris-glycine buffer, $\mathrm{pH} 8.3$, for $24 \mathrm{~h}$. The samples were concentrated approximately 5 -fold by tranferring to similar buffer containing $15 \%$ polyethylene glycol- 6000 for the final $6 \mathrm{~h}$.

Proteins in the media were analysed by an electrophoresis system based on that of Davis (1964). Small-pore acidic gels composed of $7.5 \%$ acrylamide were prepared as 8 -cm columns overlain with $1-\mathrm{cm}$ stacking gels. The sample $(200 \mu \mathrm{l})$ was mixed with 2 drops of bromophenol blue in glycerol as a tracker dye and applied to the top of the gel. Electrophoresis was carried out using $5 \mathrm{mM}$-Tris-glycine buffer, $\mathrm{pH} 8 \cdot 3$, at a constant current of $3 \mathrm{~mA}$ per gel. After electrophoresis the gels were rapidly frozen in water on solid $\mathrm{CO}_{2}$ and stored at $-15^{\circ} \mathrm{C}$. The stacking gel was cut off and formed the first slice and the rest of the gel was cut into 2-mm slices; these were all placed in separate scintillation vials containing $500 \mu \mathrm{l}$ water. The vials were capped and incubated at $37^{\circ} \mathrm{C}$ overnight; $5 \mathrm{ml}$ Fiscint scintillation fluid $(5 \mathrm{~g}$ PPO and $100 \mathrm{mg}$ POPOP/l of toluene: Fison's No. 1 emulsifier $(2: 1 \mathrm{v} / \mathrm{v}))$ were added and the samples were allowed to equilibrate before counting. The results were corrected for quenching.

The method for electrophoresis of tissue proteins was the same as that described for media proteins except that the gels and the electrode buffer contained 1\% SDS. In addition, some double-isotope gels were obtained in which two samples labelled with $\left[{ }^{3} \mathrm{H}\right]$ or $\left[{ }^{14} \mathrm{C}\right]$ leucine were combined; the total volume added to the gel was $200 \mu \mathrm{l}$ and the amount of each individual sample was adjusted so that the ${ }^{3} \mathrm{H}$ total counts added were approximately 3 times the ${ }^{14} \mathrm{C}$ total counts. For double-isotope gels the slices were dissolved in $250 \mu \mathrm{l}$ Soluene overnight and counted in toluene-PPO scintillant. Standards of RNA polymerase (mol. wt 160000 and 39000 ), albumin (mol.wt 68000) and trypsin inhibitor (mol.wt 21000 ) were used for determinations of molecular weight.

\section{Histology}

Chorion and endometrium were fixed before and after the 48-h culture period. Samples were either fixed in Bouin's solution, dehydrated in ethanol and stained with haematoxylin and eosin for light microscopy, or fixed in $4 \%$ phosphate-buffered glutaraldehyde, $\mathrm{pH} 7.2$, post-fixed in $1 \%$ osmium tetroxide, dehydrated in alcohol and embedded in araldite for electron microscopy. Sections were stained with uranyl acetate and lead citrate or phosphotungstic acid and uranyl acetate and were viewed with a Philips 300 electron microscope.

\section{Statistical analysis}

Analysis of variance or Student's $t$ test were used. 


\section{Results}

\section{Tissue preservation}

Material collected for microscopical examination is illustrated in Plate 1. These electron micrographs show that the structure of the three main types of tissue studied, chorionic, cotyledonary and intercotyledonary, was not seriously disrupted by the culture process; apparently normal mitochondria, endoplasmic reticuium and Golgi apparatus were present after culture, suggesting that protein synthesis was continuing. However, the light microscope studies showed that cells at the centre of each piece died if the pieces of endometrium cultured were too large. Although the attachment of the chorion to the endometrium appeared tenuous, the removal of the blastocyst tended to strip off the uterine epithelium. The chorion became firmly attached to the lens tissue during the culture period.

\section{Effect of steroid treatment}

The effect of culturing the material with oestradiol- $17 \beta$ and progesterone is shown in Table 1. Similar results were obtained from tissue at each stage of gestation examined so the data were pooled for analysis. To overcome the variation in control values between cows the results from the treated groups were expressed as a percentage of the control values.

For both chorionic and cotyledonary cultures the addition of steroids reduced significantly the quantity of labelled proteins which could be measured in the tissue with the greatest depression caused by a combination of oestrogen and progesterone. Although this depletion in the tissue was accompanied by an increase in labelled proteins in the medium the total amount of proteins produced per dish was still reduced (Table 1). Single isotope polyacrylamide gels were obtained from both chorion and cotyledon medium and tissue proteins. Comparisons were made within each type of tissue between control and steroid-treated samples but there were no consistent alterations in the protein profiles following particular treatments.

Table 1. The effect of steroid hormones (see text) on leucine incorporation by bovine chorion and uterine endometrium maintained in vitro for $48 \mathrm{~h}$

\begin{tabular}{|c|c|c|c|c|c|}
\hline & Proteins & $\begin{array}{c}\text { Control } \\
\text { (mean } \pm \text { s.e.m. } \\
\text { mmol } / \mathrm{mg} \\
\text { protein) }\end{array}$ & Oestradiol-17 $\beta$ & Progesterone & $\begin{array}{c}\text { Oestradiol-17 } \beta+ \\
\text { progesterone }\end{array}$ \\
\hline Chorion & $\begin{array}{l}\text { Medium } \\
\text { Tissue } \\
\text { Total }\end{array}$ & $\begin{array}{c}46 \cdot 7 \pm 5 \cdot 52 \\
(13) \\
188 \cdot 3 \pm 24 \cdot 36 \\
(13) \\
235 \cdot 0 \pm 27.21 \\
(13)\end{array}$ & $\begin{array}{c}111.5 \pm 11.34 \\
(9) \\
59.0 \pm 7.69^{\mathrm{c}} \\
(9) \\
66.8 \pm 7.42^{\mathrm{b}} \\
(9)\end{array}$ & $\begin{array}{c}141 \cdot 3 \pm 28 \cdot 25^{\mathrm{a}} \\
(9) \\
61 \cdot 2 \pm 11.47^{\mathrm{c}} \\
(9) \\
72 \cdot 3 \pm 6 \cdot 19^{\mathrm{b}} \\
(9)\end{array}$ & $\begin{array}{c}153 \cdot 5 \pm 30.68^{\mathrm{a}} \\
(8) \\
21 \cdot 0 \pm 1.69^{\mathrm{ch}} \\
(8) \\
48.4 \pm 3.47^{\mathrm{cds}} \\
(8)\end{array}$ \\
\hline Cotyledon & $\begin{array}{l}\text { Medium } \\
\text { Tissue } \\
\text { Total }\end{array}$ & $\begin{array}{c}22 \cdot 0 \pm 2 \cdot 72 \\
(16) \\
128 \cdot 5 \pm 16 \cdot 21 \\
(16) \\
150 \cdot 2 \pm 19 \cdot 58 \\
(15)\end{array}$ & $\begin{array}{c}109 \cdot 6 \pm 8 \cdot 14 \\
(12) \\
72 \cdot 9 \pm 3.96^{\mathrm{c}} \\
(12) \\
77 \cdot 4 \pm 3 \cdot 85^{\mathrm{b}} \\
(12)\end{array}$ & $\begin{array}{c}129.4 \pm 21 \cdot 38 \\
(12) \\
46.9 \pm 6 \cdot 86^{\mathrm{cf}} \\
(12) \\
58 \cdot 2 \pm 5 \cdot 11^{\mathrm{ce}} \\
(12)\end{array}$ & $\begin{array}{c}136.0 \pm 17.76 \\
(12) \\
29.4 \pm 4.06^{\mathrm{cf}} \\
(12) \\
46 \cdot 2 \pm 4.93^{\mathrm{cf}} \\
(12)\end{array}$ \\
\hline
\end{tabular}

* Values are mean \pm s.e.m. percentages of control values; the no. of culture dishes/treatment is given in parentheses.

Values significantly different from the respective control: ${ }^{\mathrm{a}} P<0.05,{ }^{\mathrm{b}} P<0.01{ }^{\mathrm{c}} P<0.001$.

Values significantly different from that for oestradiol alone: ${ }^{\mathrm{d}} P<0.05,{ }^{\mathrm{e}} P<0.01,{ }^{\mathrm{f}} P<0.001$.

Values significantly different from that for progesterone alone ${ }^{8} P<0.01{ }^{h} P^{h}<0.001$. 


\section{PLATE 1}
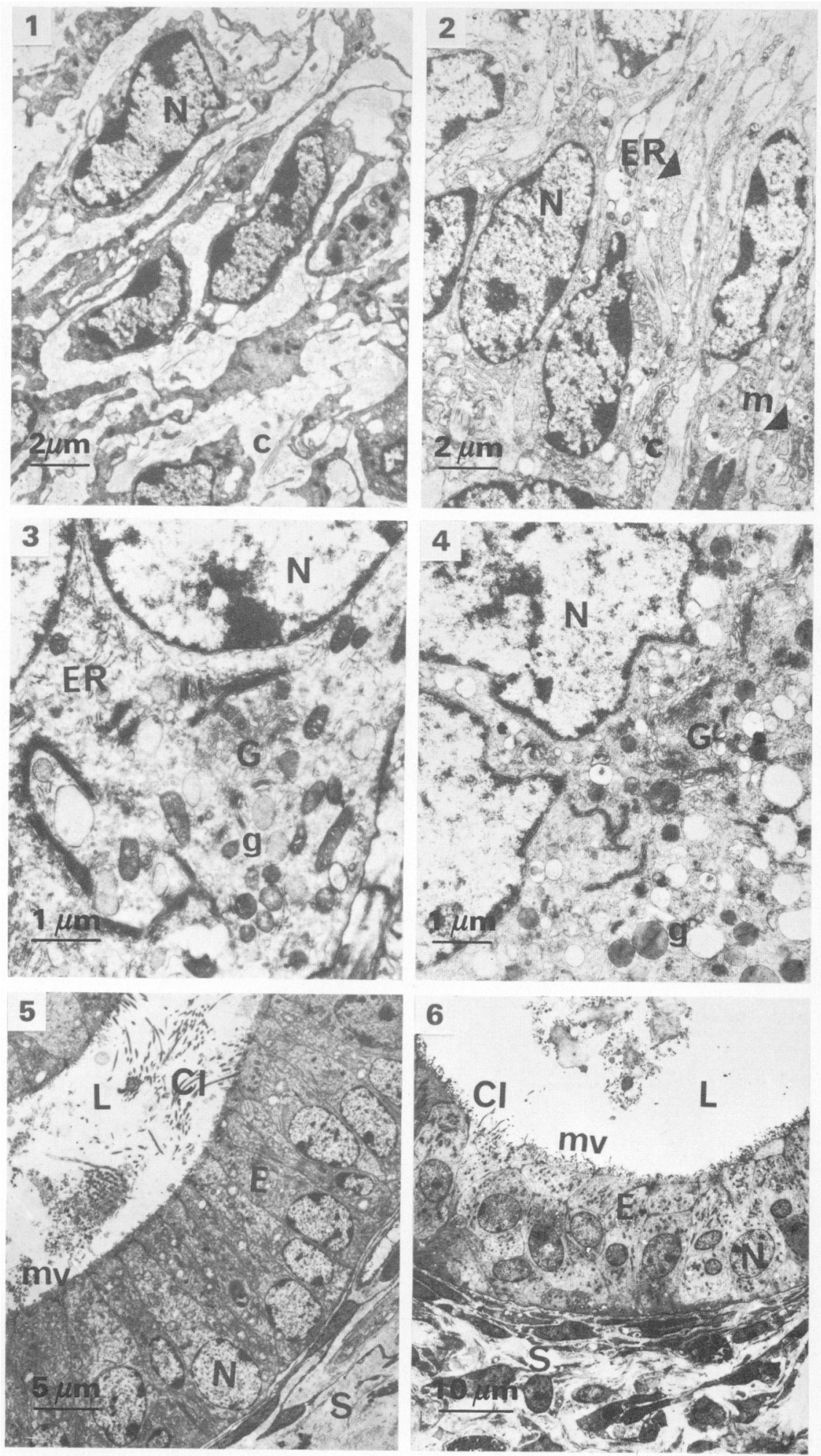


\section{Co-culture experiment}

The data in Table 2 were obtained from 5 cows and the mean \pm s.e.m. leucine incorporation by the controls (chorion cultured alone) was $165.9 \pm 15.98 \mathrm{nmol} / \mathrm{mg}$ chorion tissue $(n=21)$. Although leucine incorporation by the chorion appeared to be increased following culture with intercotyledonary or kidney tissue and decreased by liver none of the differences was significant. There was no alteration of protein synthesis when cotyledonary and intercotyledonary tissue were co-cultured with chorion (Table 2). The leucine incorporation by untreated cotyledonary and intercotyledonary tissue was $89.4 \pm 6.77$ and $87.6 \pm 6.13 \mathrm{nmol} / \mathrm{mg}$ protein respectively.

Table 2. The effect of co-culture on leucine incorporation by bovine chorion and uterine endometrium obtained between Days 24 and 29 of gestation and maintained in vitro for $48 \mathrm{~h}$

\begin{tabular}{lccc}
\hline \multicolumn{1}{c}{ Material cultured } & $\begin{array}{c}\text { No. of } \\
\text { animals }\end{array}$ & $\begin{array}{c}\text { No. of } \\
\text { replicates }\end{array}$ & $\begin{array}{c}\text { \% of control } \\
\text { value } \pm \text { s.e.m. }\end{array}$ \\
\hline Chorion alone (control) & 5 & 21 & $100.1 \pm 5.88$ \\
Chorion + cotyledon & 5 & 21 & $98.9 \pm 10.85$ \\
Chorion + intercotyledonary tissue & 4 & 18 & $121.1 \pm 9.87$ \\
Chorion + liver & 2 & 14 & $82.6 \pm 9.05$ \\
Chorion + kidney & 2 & 14 & $111.7 \pm 8.27$ \\
\hline Cotyledon alone (control) & 5 & 20 & $100.1 \pm 4.73$ \\
Cotyledon + chorion & 5 & 22 & $111.9 \pm 11.09$ \\
\hline Intercotyledonary tissue alone (control) & 2 & 8 & $99.9 \pm 6.98$ \\
Intercotyledonary tissue + chorion & 2 & 9 & $97.8 \pm 9.82$ \\
\hline
\end{tabular}

Leucine incorporation by the chorion was compared with that of the allantois and also with allantochorion from a 37-day-pregnant cow. As shown in Table 3 both tissues incorporated more radioactive leucine during the culture period than did the chorion and the combined results showed a significant difference between the two types of tissue $(P<0.01)$.

Table 3. A comparison of the amount of leucine incorporated by bovine chorion and allantois maintained in culture for $48 \mathrm{~h}$

\begin{tabular}{|c|c|c|c|c|c|c|}
\hline & \multicolumn{6}{|c|}{ Day of pregnancy } \\
\hline & \multicolumn{2}{|c|}{25} & \multicolumn{2}{|c|}{26} & \multicolumn{2}{|c|}{37} \\
\hline & Chorion & Allantois & Chorion & Allantois & Chorion & Allanto-chorion \\
\hline No. of replicates & 4 & 4 & 5 & 4 & 4 & 4 \\
\hline $\begin{array}{l}\text { Leucine incorporated } \\
\text { (nmol/mg protein)* }\end{array}$ & $\begin{array}{r}174.0 \\
\pm 10.45\end{array}$ & $\begin{array}{c}249.5 \\
\pm 41.58\end{array}$ & $\begin{array}{c}91.5 \\
\pm 20.9\end{array}$ & $\begin{array}{r}121.2 \\
\pm 22.7\end{array}$ & $\begin{array}{c}33.2 \\
\pm 5.07\end{array}$ & $\begin{array}{c}65.4 \\
\pm 16.06\end{array}$ \\
\hline $\begin{array}{l}\text { Allantois value as } \% \\
\text { of chorion value }\end{array}$ & 100 & 143 & 100 & 133 & 100 & 197 \\
\hline
\end{tabular}

* Mean \pm s.e.m.

Double-isotope polyacrylamide gel electrophoresis was used to compare protein fractions obtained from tissue cultured alone or in combination (Text-figs $1 \mathrm{a}$ and $1 \mathrm{~b}$ ). For chorionic tissue cultured with or without cotyledon (Text-fig. 1a) the only major deviation in the count ratio was obtained in the stacking gel which was the first slice. The counts were higher in this slice in 3 of the 4 gels examined but the total protein content of this fraction was low and little emphasis should be placed on this result. No other consistent differences were observed. In all four gels 
containing chorion cultured with or without intercotyledonary tissue (Text-fig. 1b), there was a peak in the count ratio at a relative mobility of about $0.47(0.46,0.46,0.47$ and 0.50$)$, with an increase above baseline ranging from 27 to $80 \%$. This suggested that more protein with a molecular weight of about 85000 was obtained from the co-cultured material. There were no other consistent differences between gels and the depression at $R_{\mathrm{F}}=0.68$ in Text-fig. $1 \mathrm{~b}$ was not found elsewhere.

Mixed gels of cotyledon and intercotyledon cultured with and without chorion did not show any positive results.

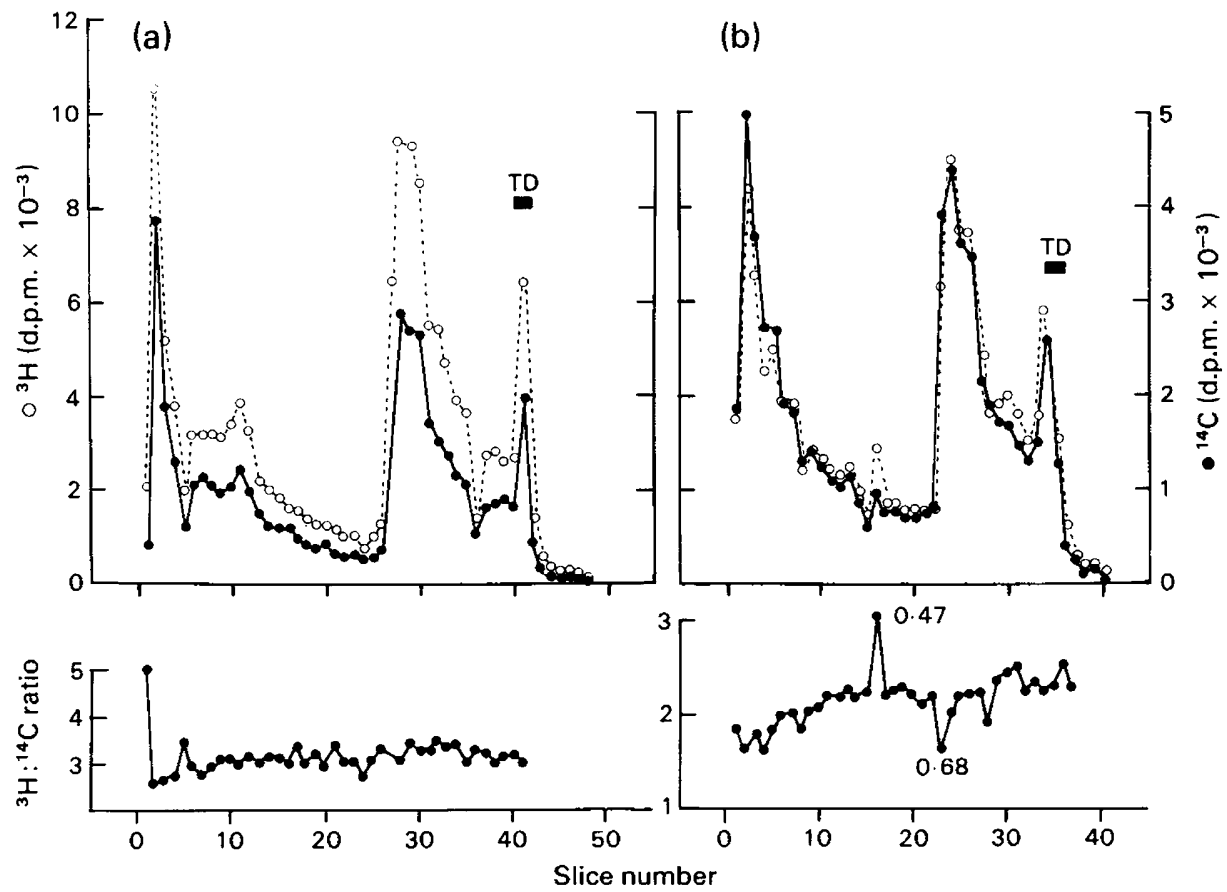

Text-fig. 1. Polyacrylamide gel electrophoresis of representative gels comparing the proteins obtained from chorion tissue cultured alone $\left({ }^{14} \mathrm{C}\right.$ ) or with (a) cotyledonary tissue or (b) intercotyledonary tissue $\left({ }^{3} \mathrm{H}\right)$ for $48 \mathrm{~h}$. TD $=$ tracker dye.

\section{Discussion}

Preliminary work by Heap, Flint, Gadsby \& Rice (1979) suggested that the pig endometrium produces a substance which stimulates protein synthesis by the blastocyst in vitro. Similar experiments were therefore repeated using bovine tissue to see if such a substance could be

\section{PLATE 1}

Figs 1 and 2. Stroma from cotyledonary tissue from a 28-day-pregnant cow fixed before culture (Fig. 1) and after $48 \mathrm{~h}$ in culture (Fig. 2)

Figs 3 and 4. Cytoplasm of a binucleate cell from 28-day chorionic tissue fixed before culture (Fig. 3) and after $48 \mathrm{~h}$ in culture (Fig. 4).

Figs 5 and 6. Gland from intercotyledonary area of a 28-day-pregnant cow fixed before culture (Fig. 5) after $48 \mathrm{~h}$ in culture (Fig. 6). All tissues were stained with uranyl acetate and lead citrate except for Fig. 6 which was stained with phosphotungstic acid and uranyl acetate. $c=$ collagen, $\mathrm{Cl}=$ cilia, $\mathbf{E R}=$ endoplasmic reticulum, $\mathbf{G}=$ Golgi apparatus, $\mathrm{g}=$ membrane-bound granule, $\mathbf{L}=$ lumen of endometrial gland, $\mathbf{m v}=$ microvilli, $\mathbf{N}=$ nucleus, $\mathbf{S}=$ endometrial stroma. 
detected and whether specific proteins were produced by the chorion or endometrium in response to steroid hormones. Control by steroids of the secretion of endometrial proteins into the uterine lumen has been demonstrated in the pig (Knight, Bazer \& Wallace, 1974), rat (Surani, 1977) and mouse (Fishel, 1979) by giving oestrogen and progesterone to ovariectomized animals. However, work of a similar nature performed in vitro has usually produced negative results. Neither Rice (1978) nor Basha, Bazer \& Roberts (1979) detected any significant effect of oestrogen or progesterone on the capacity of porcine endometrium to synthesize proteins in culture. Warner \& Tollefson (1978) reported that progesterone, alone or in combination with oestrogen, had no effect on RNA synthesis by preimplantation mouse blastocysts. The present results are similar to those of Maurer \& Beier (1976) who found that progesterone and oestrogen $\left(10^{-5}-10^{-11} \mathrm{M}\right)$ slowed the development of rabbit embryos cultured in vitro although only the progesterone effect was significant.

The higher steroid concentration of $10^{-4} \mathrm{M}$ used in the present experiments was chosen because Rice (1978) achieved no consistent effects of progesterone and oestradiol-17 $\beta$ on protein synthesis by porcine blastocyst tissue with steroid concentrations up to $3 \times 10^{-6} \mathrm{M}$ and Ricketts, Galil, Ackland, Heap \& Flint (1980) found that only 1.9 and $2.6 \%$ of tritiated cortisol and dexamethasone respectively were taken up by explants of ovine cotyledons during $48 \mathrm{~h}$. The presence of steroids in the fetal calf serum may have influenced the control samples although, in view of the low uptake, the concentrations in the medium $(0.01 \mathrm{ng}$ progesterone $/ \mathrm{ml}, 68 \mathrm{pg}$ total unconjugated oestrogens $/ \mathrm{ml}, 10 \mathrm{ng}$ total conjugated oestrogens $/ \mathrm{ml}$ ) were unlikely to have affected the results. It is also possible that the steroids did stimulate the synthesis and/or secretion of specific secretory proteins, but that the changes were not detected on the polyacrylamide gels. However, a more likely explanation for the depression in leucine incorporation by bovine chorion and endometrium is that progesterone given to tissue in vitro may inhibit the membrane transport of glucose which in turn decreases the rates of both glucose and acetate uptake and of oxygen consumption (Flint, 1970).

Rice (1978) examined the relationship between the concentration of leucine in the medium and its rate of incorporation into porcine blastocyst tissue. The concentration of leucine in Medium $199(458 \mathrm{nmol} / \mathrm{ml})$ was at the level where the rate of incorporation started to plateau, indicating that uptake of leucine was saturated and hence independent of the size of the endogenous leucine pool. Although this experiment was not repeated using bovine tissue it is probable that the level of leucine in the medium was sufficient for the rate of incorporation to give a true representation of protein synthesis.

In the co-culture experiments neither the chorion nor the uterine endometrium responded to the presence of the other by an overall increase in leucine incorporation although there was some evidence from the double-isotope gel study that the chorion synthesized an extra protein(s) in the presence of intercotyledonary tissue. It is possible, but unlikely, that this protein was synthesized by the latter tissue and transferred to the chorion via the medium. The dual isotope technique provides a sensitive method of detecting changes in the synthesis of individual proteins by cells or tissues (Mayol, 1975). Therefore the present results suggest that, if the production of specific proteins was stimulated in response to the treatments, the level of production was extremely low. Further work involving two-dimensional electrophoresis would be required to resolve this point.

The comparatively high rate of protein synthesis by the allantois was of interest as the allantoic vesicle undergoes rapid expansion at this stage of gestation to fill the chorionic sac. The results suggest that the tissue can maintain rapid growth in vitro when removed from its normal environment and presumably in the absence of any specific stimuli.

I thank the Milk Marketing Board of England and Wales for generous financial support; $\mathrm{Dr}$ R. B. Heap for advice and encouragement; Mrs J. Buckle for technical assistance; Professor G. E. Lamming for support and interest; and Dr A. P. F. Flint and Mrs N. Ackland for helpful advice. 


\section{References}

Basha, S.M., Bazer, F.W. \& Roberts, R.M. (1979) The secretion of a uterine specific purple phosphatase by cultured explants of porcine endometrium Dependency upon the state of pregnancy of the donor animal. Biol. Reprod. 20, 431-441.

Beier, H.M. (1976) Uteroglobin and related biochemical changes in the reproductive tract during early pregnancy in the rabbit. J. Reprod. Fert., Suppl. 25, 53-69.

Chen, J.M. (1954) The cultivation in fluid medium of organised liver, pancreas and other tissues of foetal rats. Expl Cell Res. 7, 518-529.

Davis, B.J. (1964) Disc electrophoresis II. Method and application to human serum proteins. Ann. N.Y. Acad. Sci. 121, 404-427.

Eley, R.M., Thatcher, W.W. \& Bazer, F.W. (1979) Hormonal and physical changes associated with bovine conceptus development. J. Reprod. Fert. 55, 181-190.

Fishel, S.B. (1979) Analysis of mouse uterine proteins at pro-oestrus, during early pregnancy and after administration of exogenous steroids. J. Reprod. Fert. 55, 91-100.

Flint, A.P.F. (1970) Effects of progesterone in vitro on glucose and acetate metabolism by the luteinized rat ovary. J. Endocr. 46, 497-506.

Flint, A.P.F., Henville, A. \& Christie, W.B. (1979) Presence of placental lactogen in bovine conceptuses before attachment. J. Reprod. Fert. 56, 305-308.

Heap, R.B., Flint, A.P.F., Gadsby, J.E. \& Rice, C. (1979) Hormones, the early embryo and the uterine environment. J. Reprod. Fert. 55, 267-275.

Knight, J.W., Bazer, F.W. \& Wallace, H.D.(1974) Effect of progesterone induced increase in uterine secretory activity on development of the porcine conceptus. $J$. Anim. Sci. 39, 743-746.

Koren, Z. \& Behrman, S.J. (1968) Organ culture of pure mouse trophoblast. Am. J. Obstet. Gynec. 100, 576-581.

Laster, D.B. (1977) A pregnancy specific protein in the bovine uterus. Biol. Reprod. 16, 682-690.

Leiser, R. (1975) Kontaktaufnahme zwischen trophoblast und utererosepithel während der frühen implantation biem rind. Anat. Histol. Embryol. 4, 63-86.

Lowry, O.H., Rosebrough, N.J., Farr, A.L. \& Randall,
R.J. (1951) Protein measurement with the folin phenol reagent. J. biol. Chem. 193, 265-275.

Maurer, R.R. \& Beier, H.M. (1976) Uterine proteins and development in vitro of rabbit preimplantation embryos. J. Reprod. Fert. 48, 33-41.

Mayol, R.F. (1975) Studies on the synthesis of estrogenspecific uterine proteins. Comparisons of methods of qualitative evaluation of double isotope peaks. Molec. cell. Endocr. 2, 133-146.

Newcomb, R. \& Rowson, L.E.A. (1975) Conception rate after uterine transfer of cow eggs, in relation to synchronization of oestrus and age of eggs. $J$. Reprod. Fert. 43, 539-541.

Rice, C. (1978) Maternal embryonic interactions during early pregnancy in the pig. Ph.D. thesis, University of Cambridge.

Ricketts, A.P., Galil, A.K.A., Ackland, N., Heap, R.B. \& Flint, A.P.F. (1980) Activation by corticosteroids of steroid metabolizing enzymes in ovine placental explants in vitro. J. Endocr. 85, 457-469.

Roberts. G.P. \& Parker, J.M. (1974) Macromolecular components of the luminal fluid from the bovine uterus. J. Reprod. Fert. 40, 291-303.

Schlosnagle, D.C., Bazer, F.W., Tsibris, J.C.M. \& Roberts, R.M. (1974) An iron-containing phosphatase induced by progesterone in the uterine fluid of pigs. J. biol. Chem. 249, 7574-7579.

Shemesh, M., Milaguir, F., Ayalon, N. \& Hansel, w. (1979) Steroidogenesis and prostaglandin synthesis by cultured bovine blastocysts. J. Reprod. Fert. 56, 181-185.

Sreenan, J.M. \& McDonagh, T. (1979) Comparison of the embryo survival rate in heifers following artificial insemination, non-surgical blastocyst transfer or both. J. Reprod. Fert. 56, 281-284.

Surani, M.A.H. (1977) Radiolabelled rat uterine luminal proteins and their regulation by oestradiol and progesterone J. Reprod. Fert. 50, 289-296.

Warner, C.M. \& Tollefson, C.M. (1978) The effect of progesterone, estradiol and serum on RNA synthesis in preimplantation mouse embryos cultured in vitro. Biol. Reprod. 19, 332-337.

Wyatt, C. (1976) Endometrial components involved in protein synthesis by 16 day pig blastocyst tissue in culture. J. Physiol., Lond. 260, 73P-74P. 